\title{
Discussion on the influence of preferential tax policies for Small and Micro enterprises in China
}

\author{
Zhaoting Zhang \\ School of Information, Guizhou University of Finance and Economics
}

\begin{abstract}
Small and micro enterprises are an integral part of the enterprise group. They drive the development of society and are also one of the foundations of social and economic development. The division and definition of small and micro enterprises have different connotations in different periods. The preferential tax policies of small and micro enterprises include both the turnover tax incentives such as VAT tax and the income tax incentives such as enterprise income tax. The implementation of preferential tax policies promotes the healthy development of small and micro enterprises.
\end{abstract}

Keywords: small and micro enterprises; preferential tax policies; influence; suggestions

DOI: 10.36012 /ems.v1i2.1832

A

$\mathrm{t}$ present, there are an increasing number of small and micro enterprises, who are greatly influenced by the market and society. When it comes to major social or market events, such as sudden disasters and epidemics, small and micro enterprises would fluctuate greatly. In order to strongly support small and micro enterprises, the state has issued many preferential tax policies. The preferential tax policies for small and micro enterprises cover many aspects, and the main purpose of implementation is to promote the coordinated development of various types of enterprises.

\section{Definition of small and micro enterprises}

What is a small and micro enterprise? Micro small and medium enterprises (MSMEs) are defined by various metrics. Generally speaking, they cover self-employed individuals, small enterprises and micro enterprises. In fact, small and micro enterprises are the concept of categories, belonging to the category of enterprise types. In China, the identification of small and micro enterprises is mainly regulated by the relevant state departments. In 2001, the Ministry of Industry and Information Technology adopted Document 300 to stipulate the standards for MSMEs classification in the form of a notice. Small and micro enterprises have different characteristics in different periods of development of China. These characteristics change with time, society, economic level and overall strength, so small and micro enterprises do not have a fixed classification and standard.

\section{General content}

China adopted different preferential tax policy policies to facilitate development of MSMEs in different periods. In recent years, the state has continuously increased its support on favorable tax policies for small and micro enterprises. The preferential tax policies also includes many types of taxes, like VAT, surcharges and income tax.

\subsection{VAT}

(1) According to 《the Further roll-out of the VAT transformation Pilot Program》([2016] No. 36) : VAT will not be imposed on small-scale VAT taxpayer in enterprises or non-enterp rise, who did not reach 20,000 yuan in sales this month. By 2018, VAT will not be imposed on smaller VAT payers, like some enterprises with monthly sales of only 20,000 to 30,000 
yuan, and non-enterprise units.

(2) According to 《Notice of The State Administration of Taxation (SAT) on continuing the VAT tax Policy for MSMEs》 ( [2017] No. 76): In order to support and facilitate MSMEs, from the beginning of 2018 until the end of 2020 , VAT will not be imposed on some enterprises and small VAT taxpayers, whose monthly sales only 20,000 to 30,000 yuan.

(3) According to the specific provisions in the 《 Notice of the State Taxation Administration (SAT) on issues concerning VAT reduction for MSMEs》, from May 1, 2016: small-scale VAT taxpayers need to calculate separately the tax exclusive income from sales of goods, repairing/ processing/replacement services and the tax exclusive income from sales of services and intangible assets. From the beginning of 2018 until the end of 2020 , small-scale VAT taxpayers , who still sell goods, repair/ processing/replacement service , with monthly tax exclusive income less than 30,000 yuan, may still enjoy the preferential policy.

\subsection{Construction Fee for Cultural Undertakings}

According to regulations, construction fees for cultural undertakings will not be imposed on the small-scale VAT taxpayers, with monthly sales of less than 20,000 ,from the beginning of 2015 until the end of 2017, according to the law, construction fees for cultural undertakings will not be imposed on taxpayers with monthly sales of less than 30,000 (monthly) or quarterly sales of less than 90,000 (quarterly).

\subsection{Enterprise Income Tax}

(1) As stated in Article 28 of 《 The Law of the People's Republic of China on Corporate income taxes $\rangle$, For small and low-profit enterprises that can meet the requirements of the conditions, may enjoy preferential corporate income tax with about $20 \%$ rate.

(2) According to 《Announcement of the State Administration of Taxation on expanding the scope of preferential corporate income tax for Small and Low-profit Enterprises 》: from the beginning of 2017 until the end of 2019, corporate income taxes threshold on small-scale tax payers, which mainly includes MSEs and individual businesses and other types of individuals, will be raised to 500,000 yuan annual. Small and low-profit businesses with an annual corporate income tax of less than 500,000 will be eligible to have their tax calculated based on 50 percent of their tax- able income at $20 \%$ tax rate. When small and low-profit businesses make prepayment, it may enjoy corporate income tax reduction. However, once it is found to have exceeded the standards during the settlement and payment of annual enterprise Income Tax, small low-profit enterprise needs to pay taxes in accordance with the regulations.

\section{The influence of preferential tax policies}

\subsection{Burden reduction and sustained development}

Burden reduction is an important measure for enterprise development. MSMEs play an important role in national strategic layout. The development and growth of MSMEs is an important goal. Burden reduction can speed up development of small and micro enterprises. It is especially important to reduce the tax burden of small and micro enterprises. The government regards the development of small and micro enterprises as an important task, and ensure the in-depth goal of sound and sustained development of MSMEs s through tax reduction.

\subsection{Improvement of business environment and strengthen the development of MSMEs}

Due to their small size, MSMEs cannot produce obvious and huge benefits, and local governments do not have obvious supportive policies for small and micro enterprises in attracting investment or developing. It is difficult for small and micro enterprises to get listed directly, and also difficult for them to directly raise funds in various financial institutions, and the scale of loans is very small. Therefore, the business environment is not that good, they cannot quickly enhance their own strength and develop slowly, some even fall into the civil usury storm, which is not conducive to the development of small and micro enterprises. Therefore, appropriate tax reduction should be given to enterprises, so that enterprises can obtain more disposable income, obtain funds needed for their daily life, and improve their reinvestments ability and competitiveness.

\subsection{Indirectly promotions of employment rate and harmonious development of society}

The employment rate of the society is an important indicator in the development of the country. The employment situation of small and micro enterprises is very flexible. They are very large in number, small in scale and flexible in employment, and they act as a 
reservoir. The Report on the Development of MSMEs released by the Ministry of Commerce and Industry shows that, generating about 70 percent of GDP and 80 percent of jobs, MSMEs have emerged as important pillars that support both the economy and social stability .The development of small and micro enterprises play a crucial role in expanding employment and improving people's livelihood.

\section{Policy deficiencies}

\subsection{Insufficient policy stability}

The preferential tax policies of MSMEs are usually characterized by stages. The release of such preferential tax policies usually needs the help of provisions and notices of national ministries and commissions. The tax policies in china are flexible to meet the needs of the economy, but there are also some problems such low-level and obvious temporary features.

\subsection{Many restrictive clauses}

There are many restrictive clauses in preferential tax policies for MSMEs, which are stipulated in terms of industry, assets, number of employees and other conditions at the same time. Threshold is high still, the application of a lot of individual or family workshop is fuzzy. There are many MSMEs that do not meet the national standards, and can not enjoy the preferential tax policies.

\subsection{Inadequate policy tools}

Foreign preferential tax policies have been adopted in many ways, such as tax reduction and exemption for investment credit, tax refund for reinvestments, deferring tax, accelerating depreciation to increase the deduction, tax deduction and so on. In our country, tax rate reduction and regular tax reduction are generally adopted, but indirect preferential is seldom used. If MSMEs does not have profit, they may not enjoy the preferential tax policies, which is actually not good to their future development and growth.

\section{Improvement suggestions}

\subsection{Improve policy stability}

The preferential tax policies for MSMEs are relatively disrupt. They are included in the Income Tax Law, as well as in the departmental regulations of the State Taxation Administration(SAT) and the Ministry of Finance. A relatively complete system of preferential tax policies for MSMEs has not yet been formed. In order to achieve solid preferential tax policies for MSMEs, one is to formulate a relatively complete legal system, with a complete system from NPC regulations to departmental rules. Relatively stable regulations and systems with preferential tax policies for MSMEs can support the stable development of MSMEs.

\subsection{Increase policy strength}

At present, although there are many preferential tax policies for MSMEs, there are also many restrictive conditions and policies are not as strong as developed countries. Moreover, the tax system is very strict in the supervision of the preferential policies, causing some small companies giving up the preferential tax policies. We should strengthen research, expand standards for the size of small and micro businesses, expand the scope of policies, continue to reduce relevant tax rates.

\subsection{Improve enterprises management}

The scale of MSMEs enterprises is small and the financial structure is imperfect. Therefore, the staffs of MSMEs should regularly study preferential tax policies, thoroughly understand the key words of policies, and help enterprises truly implement policies and reduce tax burdens. At the same time, MSMEs should develop their soft power and enhance their competitiveness.

\section{References}

[1] State Administration for Industry and Commerce. 《Report on the Development of National Small and Micro Enterprises》 (Abstract) [EB/OL]. (2014-03-31)

[2] ZhenDong Chen. The voice of structural tax cuts is high. China Taxation. 2012 Fourth Issue

[3] JiangYu Xia, YanYun Liu. Research on the Tax Preferential Policy System for Small and Micro Enterprises Based on Corporate Social Responsibility [J]. Business Economics Research, 2015, (15): 88-90. 